\title{
Management Open Junior High School during the Nine Years Compulsory Education Programme in Malang
}

\author{
Soetyono Iskandar \\ Makassar State University
}

\begin{abstract}
The management of nine year compulsory education of open junior high school, the principal as the educational manager is required to perform his perserverance and skill in running the school education system. This research applies qualitative research approach with the design of multy-sites research and applies the technique of data. Assembly through deep interview, observation and document. To coincide with the research goal, the research focus is as follow: (a) The school plan in running open Junior High School during the nine years compulsory education programme in Malang. (b) The organizing of executing open Junior High School during the nine years compulsory education programme in Malang. (c) The development of the executor source in running of open Junior High School during the nine years compulsory education programme in Malang. (d) The management audit system of open Junior High School during the nine years compulsory education programme.

Result of the research is as follows: First, the staff management plan should have done as the design management school. It is necessary to support the system of development and placement for the good and exact teachers and tutors. The principal needs creating conducive atmosphere in such a way that the management executor that is the teacher/tutor is involved in formulating yhe management execution and they are expected to participate proactively in contributing ideas on the operational of the school management. Second, The available organization basically has run well and has functioned yet as it is required, yet the ordering better system and working procedure are still needed so the coordination between the principal and the teacher/tutor internally and externally can be improved. The principal has to arrange the form/executing operational standard of each school to eliminate fragmentation. Third, The development of the available source needs better planning usage and improvement to support the execution more effective and efficient management. Any principal has to work hard to assure the teacher/tutor to execute management reformation for the sake of the school existence and continuance in the future. The utilization of the training result needs the support of recruitment system and teacher/tutor appointment, so there will be an obvious form/executing operational standard between the principal and teacher/tutor in selecting the needed teacher/tutor with his principal field. Fourth, Management audit system Improvement of the teacher/tutor competence and quality in every school. In his case, every principal has to improve the message quality that is addressed to the teacher/tutor through the comprehension of "what, why, when, where and how" about the management on the teacher/tutor competence improment so it will be more obvious. Besides, every principal needs formulating the strategic steps to advance the effectiveness of management communication to all the teachers/tutors. Further, the teacher/tutor is expected to give feed back to complete the message substance delivered by their principal. The education executor management should take the benefit of the research result as an asset to expand the school in future. Furthermore, it will be much better, if the educational execution management is supported by interscholastic in endeavoring and taking the benefit of the capital owned by the stakeholders or through the rotation pattern as what is recently performed by Directorate General of Higher Education Ministry of National Education Malang. This can also be applied as an effort to refresh as well as to expand the teacher's/tutor's academic. Afterwards, the educational executor management with its regular method and immediate start.
\end{abstract}

Key word: Management open Junior High School during the nine years compulsory education programme.

Base education, that Indonesian education as junior (SD), junior high school (SMP) or as a level school (Sukmadinata, (2007:255).

Government Strategy for the nine year compulsory education, result indicator included as: (1) mayority population education minimaze Junior High School; (2) to increase learning culture at the community that much participantion at The Junior High School regular, as course and community education program; (3) to increase population unfortunately to reach opportunity education. (Rochaety, 2005:37).

Policy strategy planning National Education Minister in 2005-2009 pointed that rebuild national education till 2025, education for aging population in Indonesian 7-15 year man and woman could be received at formal education and integrated with inclusive education. Beside it, population age 13-15 year develop at the open junior high school with service model as altenative education. (Depdiknas, 2006:40). 
Government region UU No. 32 Tahun 2004, in policy formulate region autonomy. Management special education as institution, curriculum, human being source, funding operational and infrastructure. So management region education more effective, and could be implementation at the region. Government role Nomor 25 Tahun 2000 have given, but could be done as the region.

Managemant education at region, Rochaety (2005:54) said one factor tahat could not be enjoyed the quality of education because management education professionally still low. Management education and commitment government for reaching the higest. Rochaety, (2005:54) said that still many between their have not experience and back ground with its education knowledge in management education. For effective the implementation must done at the principle professional in management program education.

At the open Junior High School during the nine years compulsory education programme, we hope principle of the school as manager. For managing open junior high school more effectively, education at the school could managed with expert and flexible. We hoped could managed all of problem processing at the open Junior High School during the nine years compulsory education programme.

The condition of Malang' education increased quality of the human being source, served average the increased of the population education. A larger composition education of the population still low, since efforted the building of education delay. The building of Malang' education efforted to increased of the quality and competence community, so their participation and function more useful and significant in building the nation. Malang'Government, (2009:11).

Open Junior High School;

"Open Junior High School was a subsystem at Junior High School education that made the best student in learning for itself with guide from other person” Depdiknas, (2005:5).

Open Junior High School as a model alternative served education that managed from regular Junior High School. Regular Junior High School managed education with dual system, means served two group student with a different learning. Open Junior High School served education far distant education system for obstacle student. Operation the Open Junior High School have visi, misi and purpose that same with national education purpose.

Sergiovanni, (1987) that: the principle management consisted of the purpose activities, so that all of the school worked as the purpose school that where it wanted to reach. As activity management education that towards each teacher done to teach exactly dan correct. The principal emphasized at the procedure and resulted to reach the purpose of the school, and leader aspect emphasized renewal and change and focus at human interactions for fluently other to reach organization purposed.

Dual system (leader and administration) as a balance and support between one to another.

Learning and teaching by teacher, where the student could developed competence and intellectual itself. Teacher managed its class as characteristic each lesson and evaluated each student' development. In the classroom teacher have done any innovation and creative learning, to manage the class, room etc.

This researcher aim focus were; how to manage Open Junior High School during the nine year compulsory education program at Malang. Reseacher fokus have four subfocus as were: 1. School design about open Junior High School during the nine year compulsory education program at Malang; 2. Organization the open Junior High School during the nine year compulsory education program at Malang; 3. Management developed power source open Junior High School during the nine year compulsory education program at Malang; 4. Management audit system open Junior High School during the nine year compulsory education program at Malang.

Description reseacher'aim have managed the open Junior High School during the nine year compulsory education program at Malang. Special reseacher'aim were: 1. Design school description about open Junior High School during the nine year compulsory education program at Malang; 2. Organization description open Junior High School during the nine year compulsory education program at Malang; 3. Management description power source developed open Junior High School during the nine year compulsory education program at Malang; 4. Management audit system analysis and description open Junior High School during the nine year compulsory education program at Malang.

This research have hoped and uselful could benefit for: 1. Region Government at Malang, Malang'Government education with policy open Junior High School during the nine year compulsory education program, the result of research could done monitoring and evaluation against management open Junior High School during the nine year compulsory education program at the far region. So that could action to repair and develop the good goal as government and community' hoped; 2. For Education Province and minister at the development knowledge, and result of the research needed for development policy education open Junior High School during the nine year compulsory education program; 3. For principal open Junior High School during the nine year compulsory education program to increase the maximum of the open Junior High School during the nine year compulsory education program; 4. For other research, could done advance research with design as this research or the different research approach. 
The management open Junior High School have done system, role, thinking, attitude, action at the systematic design; at the aspect organization to reach the goal of implementation in this research where have done by human being source at its characteristic and culture; with audit evaluation process could resulted judgement. The American Accounting Association definition auditing as: "A systematic process of objectively obtaining and evaluating evidence regarding assertions about economic action and events to ascertain the degree of correspondence between these assertion and established criteria and communicating the result to interested users." (Schawandt \& Halpen, 1988:19)

The aim of audit was to obtain evaluating evidence regarding assertions about economic action and events to ascertain the degree of correspondence between these assertion and established criteria and communicating the result to interested users. Benefit of audit as activity control included education activity.

\section{Method}

This research used quality approached. Quality research approached by Bogdan dan Biklen (1998) said; quality research was; observation the person at environmental life, effort to know its language and its around. Management open Junior High School was institution education, that given opportunity to student finish its education. To know what phenomenon about it. What unknown and bersifat inductive character in concept development at the data.

Quality research have done with several phenomenal research characteristic were: (1) to ascertain the social fact, although in interaction certain situation; (2) emphasized subjective behavior from subject that the research; (3) several manner to interpretation each individual experience or interaction experience one to another; and (4) the real experience, cause in social life (Bogdan \& Biklen, 1998).

This research design the open Junior High School was. Multi-site, could be hoped to use in theory development. Because thi research have done more than one site. As with Bogdan \& Biklen (1998;2) said;

When researchers study two or more subjects, or depositories of data they are usually doing what we call multi-site studies. Multi-site studies take a variety of forms. Some start as a single site only to leave the original work serve as the first in series of studies or as the pilot for a multisite study other studies are primarily single siie studies but indude less intense, less extensive observation at other sites for the purpose of addressing the question of general izability. Other researches do comparative site studies are done and then compared and contasted.

From quotation could known that main characteristic multisite was if researcher two or more subject, or the place to keep data with comparation. This researcher design multisite given more in good experience, experience although difficult at the theory thinking and skill in collecting data, and design approach type was "constant comparative method.." collected and analysis data for developing descriptive model that cover all phenomenon sites. in constant comparative method, each step in researcher were as; (1) collected data at fisrt site, open junior high school Teratai. Researcher have done the change processed category at the school; (2) observation at site second, open junior high school Tulip. This aim of the observation for principal school management at the change processed; (3) the next researcher at site third open junior high school Mawar, with the same aim. Although collected data in this researcher done with step by step, in special event, have done with simultaneous observation, like at the school program, activity and a certain event that needed a special time. In this researcher used event to know the data.

Comparative site study. That means comparative multisite study design to adopt from idea Bogdan \& Biklen (1998), that obtain comparative multisite study from each site, continue with compare the different and equal the invent between sites, than the next to draft the invent, proposition and teori substantively theory between sites as the final invent.

In design research comparative multi-site study ini have done with two manner, were: (1) single cases study, was description each site, that as the beginning in compare with other site (the pilot for a multi-site studies); dan (2) multi-site study, was comparative study between site (comparative site studies) yhat will be compared from three sites where be researching.

So more clear, this research design have done as the shown Figure 1 next.

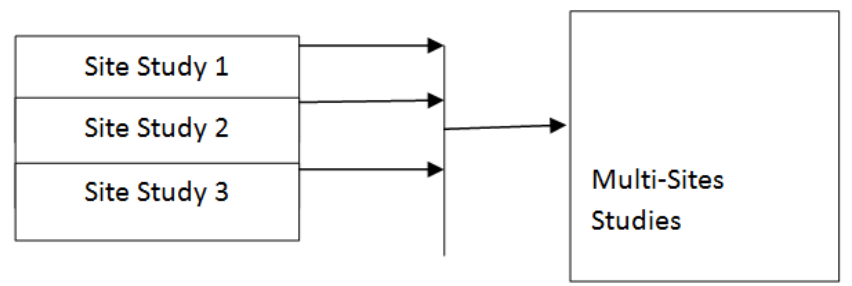

Figure 1 Research design Multi-cases Study (Three Cases), with two kind Study was Singgle Site Study and Multi-Sites Studies 
In this research, researcher come to the field, with three resaon that research: (1) as research informant; (2) last decision at the researcher, (3) follow a good ethics that have done at sites 1, 2 and 3; (4) no change at the ack ground research; and (5) follow the role at cases 1, 2 and 3 the decision as design, organization, power source and audit.

Subject of this research penelitian were 3 (three) sites, SMP Terbuka 01 di SMP Neg. 02 (SMP Terbuka Teratai) Kecamatan Klojen-Malang at centre business region and between two market (the big market and comboran market). SMP Terbuka 02 di SMP Neg. 16 (SMP Terbuka Tulip) Kecamatan Blimbing-Malang near terminal and between two (Araya resident and Teluk resident). SMP Terbuka 05 di SMP Neg. 18 (SMP Terbuka Mawar) Kecamatan Lowokwaru-Malang at Geria Santa resident althogh at the centre activity.

Source data this research as respondent that made decision organization culture and informant that known phenomenon maker decision organization culture at the institution. So enough and more higher at this research data valid, so needed to obtain the informant as source data, with taken the sampel research. Technic that used was purposive sampling, internal sampling, dan time sampling (Bogdan \& Biklen, 1998).

Used to obtain tha data with quality and total that in this research was used snowball sampling, that the beginning research come to informant that maybe have information about this research (key informant). After enough information, informant could said another informant. Informant as the new informant from method snowball sampling.

Technic collected data in this research used technic: (1) deep interview, (2) observation, and (3) document. Technic that choose with decision that collected data quality research used interview, observation and documents. Bogdan and Biklen, (1998). Research with design study case technic obtain its data with interview, observation and document.

Analysis technic data as process made and drafted with systematic all transcript interview, report filed, and other material that have written by research during collected data (Bogdan \& Biklen, 1998). This research individualist analysis procedure data said about Miles and Huberman (1992), with its step: (1) reduction data, (2) disply data, and (3) conclution drawing/verifying. The step of analysis data case individualist continue to analysis multi-case Bogdan \& Biklen (2003) dan Yin (2002). Technic model analysis data in this research was done till invent the answer as focus research, with indicate: (1) no case that contrary, (2) have the chain that entirely and logic, and (3) agree its righteousness by the informant (Faisal, 2005).

As research with design multi-site study, analysis data this research as Bogdan \& Biklen (1998), and Yin (1984) said, that have done with two steps, were: (1) anaslysis data site individual and; (2) analysis data betweet site. Anaslisis data site individual was analysis data at each research subject. So in this research analysis data single site have done at site 1 SMP Terbuka 01 Kecamatan Klojen, site 2 SMP Terbuka 02 Kecamatan Blimbing, site 3 SMP Terbuka 05 Kecamatan Lowokwaru,.

Procedure analysis data case individual in this research adopted from Miles dan Huberman (1992) as the figure 2 .

"model comparative", as the next figure:

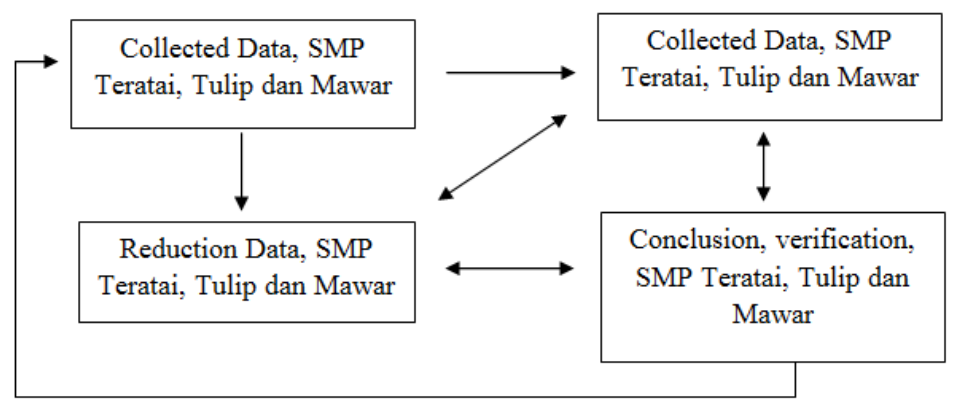

Figure 2.1. Model Interaction Analysis Data Site individual (Miles dan Huberman, 1992).

Analysis data in this research used technic circulation the constant comparative method, that method used step circuit all at once and the analysis always reverse to collect data step (Bogdan \& Biklen, 1998).

So the data have a valid research, therefore needed to recheck the valid data (trustworthiness). Analysis data this research adopted from Lincoln and Guba (1985), were used technic: credibility, dependability, and confirmability.

This research modification from Bogdan \& Biklen (1998), Creswell (2005), and Moleong (2005) were: plan, come to field, technic collected data, technic analysis data, conclusion, and report. 


\section{Result}

\section{Research invented between Site and Proposition at Management Activity Open Junior High School (SMP Terbuka).}

Result analysis multi-sites, the research invented between site and proposition school management activity, were (1) research invented between site and drafted proporsition planned school about management Open Junior High School; (2) research invented site and drafted proporsition management organization at the Open Junior High School; (3) research invented between site and drafted proporsition development power source at the management Open Junior High School; and (4) research invented between site and drafted proporsition system audit management at the Open Junior High School.

\section{1). Research Invented between Site and Proposition Planned School at the Open Junior High School.}

(a) The Planing of the school, principal have done any policy for increasing competence of the teacher at the school, although have weakness at effort the management shool was the principal style that did not known the condition of the school so the management as unconcern.

(b) The principal potency, most of the management school could not done excellent. Because most obstacle than factor to support it. Obstacle from very low the humanity quality, so uncreative. Each management only for this time, if have a new one that could not used it.

(c) Principal motivation and desire for adavancing the school must a good supported from another, but principal attitude that proactive and projection. The good management, factual and all of known about it. Optimal socialization before done the management.

Scheme comunication management with dimension as figure 3.1. shown as the next:

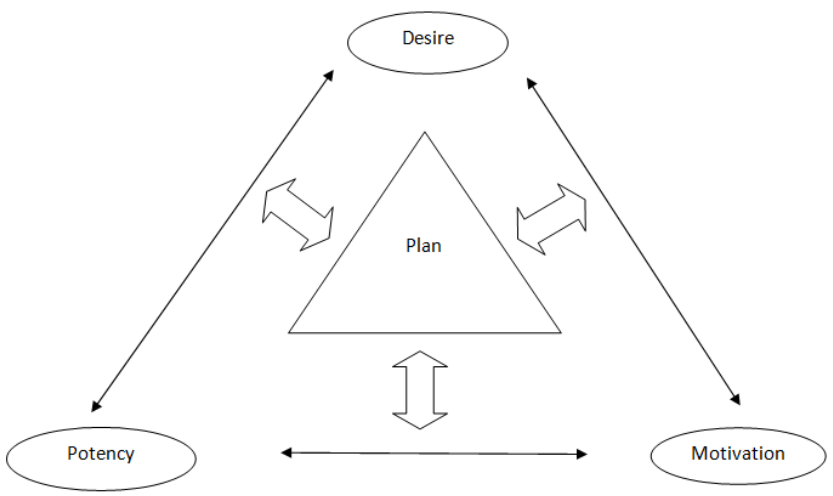

Figure 3.1. Planned School about Management at Open Junior High School

\section{1) Proposition Research about Management School Planning at The Open Junior High School}

P1.1 Teacher attitude against management planned manajemen confirm by school climate, succeed and easi relation one to another with full surrender.

P1.2 If the teacher have desired, potency and high commitment from principal attitude, therefore school management planning effectively.

P1.3 If principal could used their vice, then principal have done its good job $75 \%$.

P1.4 If Jika discipline and responsible could done with full knowledge, then the school management have done $60 \%$.

P1.5 Every principal have unique attitude managed it school, then school have a actual imaged and interested at the management school.

\section{2) Research invented betweet Site and Management Proposition organization at Open Junior High} School.

(a) Organization structure the efficiency organization school imaged, good or not. It have seen between its organization school. If organization structure at another, it was depended at the each Characteristic school, there are school the result have done the opened character. There are school the result have done closed character, and there are no ascertain character.

(b) The good organization structure if its managed always at the clear standard visi misi school, then its result would at its structure. But if have done far from the standard visi misi, then its result would not clear and no towards. 
(c) The urgent coordination at the management school have a clear job description and responsible. With the good job description occoured the good coordination, so that have the towards responsible and this school coordination was the urgent for it.

(d) Benefit power source as the urgent part at the management school, it was usual as function at the all jobs to vice principal and the teacher so that could have a good discipline and responsible. So that the school with its dimension could seen at figure 3.2. as the next.

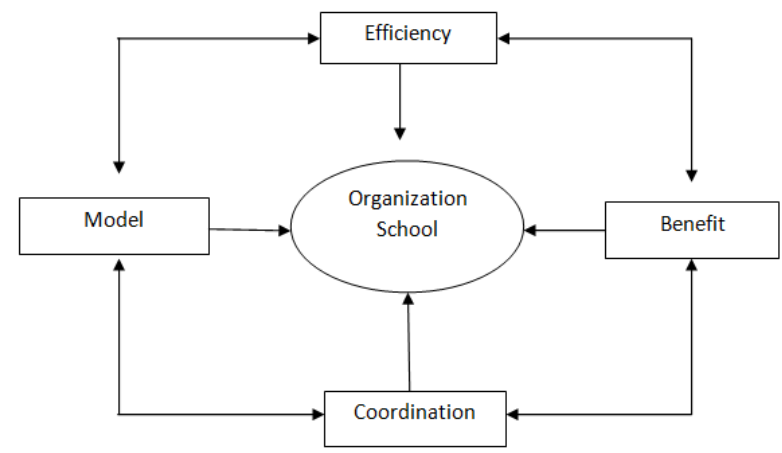

Figure 3.2. Management organization at the Open Junior High School.

\section{2) Research Proposition about Management Organization at The Open Junior High School}

P2.1 If organization have done good, since not appear unhappy and bad.

P2.2 The good organization structure would be supported all of continue with clear organization.

P2.3 If the good organization structure continuing and sipporting with done effective, efficiency, the clear Model, the good coordination and everybody done it, since the school would be succeed.

\section{3) Research invented between Site and Development Proposition Management Power Source at the Open} Junior High School.

(a) Quantity of the school still deceased teacher, since principal used honor teacher as with its need. But the quality teacher could not teached in the class, even still many teacher could not used the technology in other jog. Since the school could be imaged with power source like that, the teacher could supported the effective management school.

(b) The weakness of teacher at school, their english language, computer, access internet, even its knowledge undevelop because the teacher still in conventional. How could supported the effective implementation and a good management school.

(c) Physical facility and instrument at the school, only as useful not yet optimal and have no maintenance. So the facility instrument was no useful, even for another school have no maintenance. Because have no budget for maintenance and always was forgotten at its budgeting, so that the scholl could not payed the labor and technician. During quality, facility instrument at the school available, still good, only decreased its maintenance and damaged.

(d) From source of the budget for costing of the school was enough, but weak at managed the funding. Because attitude management have not discipline with using the money, many payment have not with the budget, that not at the field as the needed, and have not used to the priority scale that have a real budget. Principal still have a high speculation mental, without the right thought, and the final borrow funding. Funding, implementation management school have not optimal by the principal, because pay attention at the physical change school. How clear design integrated audit management school with its dimension see figure 3.3 as the next;

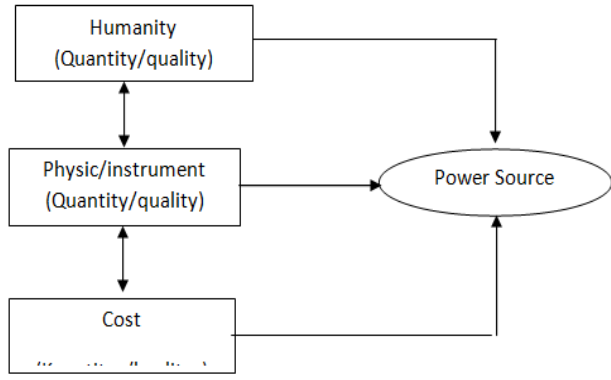

Figure 3.3. Development Managemant Power Source at The Open Junior High School 
3) Research Proposition about Development Management Power Source at the Open Junior High School.

P3.1 If humanity source at the school about quantity and quality have balanced, even acceleration occurred at the succeed management activity school.

P3.2 Facility instrument have prepared at the school would impact positive against progressive technology that could build self confidence of the teacher at the school, but the quality would impact against formed crisis level, creativity and innovative at the management school.

P3.3 If the good budget have supported the management school, so that the education would be more progressive and a good character.

P3.4 If power source have prepared at the school, the teacher could used all of with optimal, principal and student would have a good quality against management school.

P3.5 Quality management school would done excellent, if have supported with al the stakeholder at the school.

\section{4). Research invented between Site and Proposition System Audit Management at the Open Junior High}

\section{School.}

(a) Management school have supported the principal at the audit management that would said to the teacher at the school. Principal managed the school in communication as source that audit the management, so that could be excellent, qualiy, effective and professional.

(b) Principal have done the management school with skill of the principal used systematic communication, with action body intonation that given a good self-confidence to their teacher as the getting message.

(c) Communication that principal have said to be known, if the communication have supported by objective source message, even created the urgent communication.

(d) Communication that experience principal, religiously, excellent as the leader, all the message have said more self-confidence of the teacher. Very different if as asually communication of the principal.

(e) The context message content that the principal have said in audit management school to the teacher with effective, quality and professional if the message up to date, transformational, clear, valid and unchanged or consistent so could be responsible.

(f) For the new message management have said as the right message to the teacher not the old message, so the teacher wanted to know that message.

(g) Transformational that message have said as the actually fact occured to the community and needed to know with good. The message'content needed actually fact to the teacher, not only for a special group.

(h) The clearness message even each message of management that principal have said would effective if the message could be received with good to the teacher done management school, so the objective actually message.

(i) The message would be efective and quality if in the principal comunication message have said with accurately, right and as the observation, discussion and with the high commitment, so that the message more in the self-confidence.

(j) Besides, principal have done the message with audit would given effect against the teacher if have said not consistent, always change and uncertain. If principal have said the message not change as the content and purpose the teacher could be effective and done its all the message. All the order not far from the aim, visi, misi, that could done to everyone at the school.

(k) Principal have audited with more believed the actually fact, if its communication have supported with any message could be received and very representative to give the mean against the message that have done in audit management so that could known by the teacher with good.

(1) Principal' message audit management school have done for its teacher have received with good, the weakness of the style principal said unconditional that deceased self-confidence our teacher to receive the message. So many effects the audit message could be received with good. How integrated communication management school with dimension see figure 3.4. as the next;

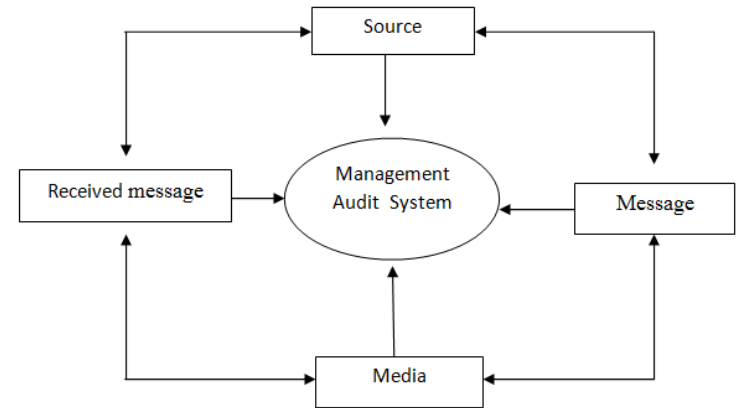

Figure 3.4. Management Audit System at the Open Junior High School. 
4) Research Proporsition about Management Audit System at the Open Junior High School.

P4.1 If principal with management audit system around the school socialization and good, so that management implementation school could be effective and excellent.

P4.2 The effective management audit school would created if supported the source information could be responsible, although from expert information, reference that supported the information, although the accurate righteousness level could believed credibility level.

P4.3 If principal at the management communication school could done with good, would created the teacher'confidence as an excellent receiver.

P4.4 School management audit that effective would created supported message, from fact, clear, up to date with as the visi, misi, that be hoped.

P4.5 School management audit that effective would created to support as much as message used, made easy to said that information and representative the actually message.

P4.6 School management audit that efective would created to receive message infrastructure as the clear source comunication.

P4.7 School management audit that efective if source supported could responsible all the information have said, with the clear message, and for the believed receiver and representative.

\section{Invented formulation at three Sites were: at SMP Terbuka Teratai, SMP Terbuka Tulip and SMP Terbuka Mawar at the Malang Region.}

Table 3.21. Invented formulation school Planned about management have done at Site I SMP Terbuka Teratai, Site II di SMP Terbuka Tulip and Site III SMP Terbuka Mawar at Malang Region.

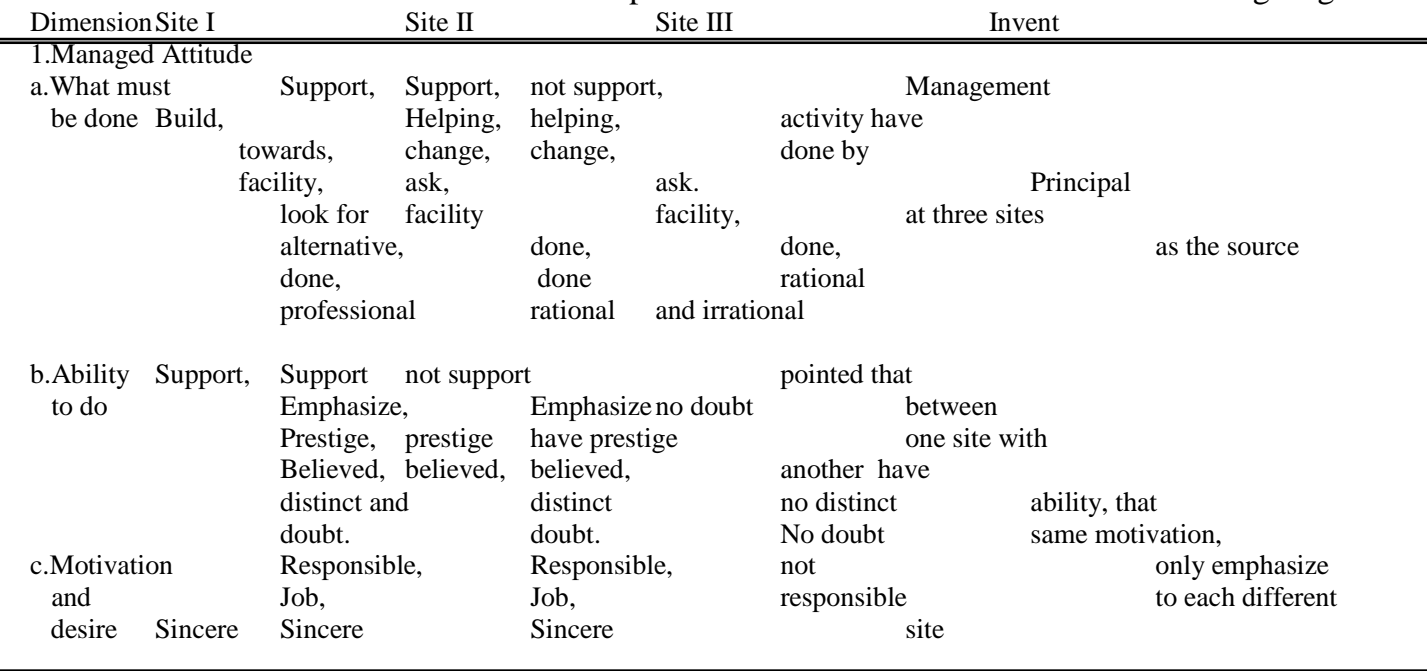

Table 3.22. Invented formulation Management Organization have done at Site I SMP Terbuka Teratai, Site II SMP Terbuka Tulip, and Site III SMP Terbuka Mawar at the Malang Region.

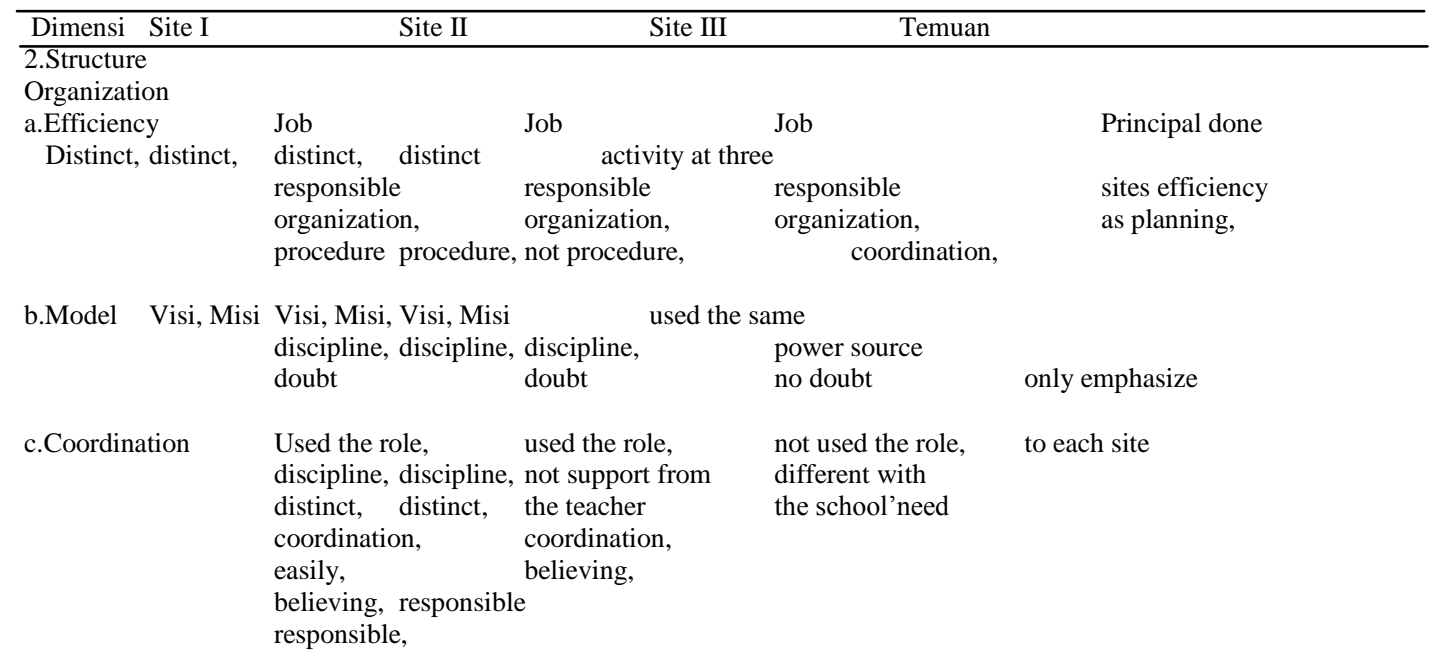


d.Useful Function, Function, Planning no action

power source responsible responsible no supported from

discipline discipline the teacher.

Table 3.23 Development Invented Formulation Management Power Source that have done at Site I SMP Terbuka Teratai, Site II SMP Terbuka Tulip, and Site III SMP Terbuka Mawar at the Malang Region.

\begin{tabular}{|c|c|c|}
\hline Dimension & Site I & Invented \\
\hline $\begin{array}{c}\text { 3.Power Source } \\
\text { a.Humanity }\end{array}$ & $\begin{array}{l}\text { Received Received } \\
\text { teacher, teacher, } \\
\text { academic academic } \\
\text { akademik akademik } \\
\text { prepared for } \\
\text { teacher, teacher } \\
\text { book changing }\end{array}$ & $\begin{array}{l}\text { Received Humanity power source } \\
\text { teacher, activity at three sites } \\
\text { academic could prepared the } \\
\text { akademik instrument facility, } \\
\text { prepared for teacher prepared for maintenance, and funding, } \\
\quad \text { as the same criteria, } \\
\text { book changing,book changing, only each different site } \\
\text { learning permit,learning permit, as school needed }\end{array}$ \\
\hline $\begin{array}{l}\text { b.Physic/Increased, } \\
\text { facility prepared, } \\
\text { and } \\
\text { instrument }\end{array}$ & $\begin{array}{l}\text { Repaired, Prepared, } \\
\text { maintenance, } \\
\text { maintenance, } \\
\text { procedure responsible } \\
\text { responsible } \\
\text { doubt, } \\
\text { distinct, }\end{array}$ & $\begin{array}{l}\text { Repaired, } \\
\text { procedure unguarded, } \\
\text { e maintenance, } \\
\\
\quad \text { procedure } \\
\text { not doubt, }\end{array}$ \\
\hline c.Funding & $\begin{array}{l}\text { Budget Budget } \\
\text { finding } \\
\text { sponsorship } \\
\text { Billing } \\
\text { Discipline, discipline, } \\
\text { The fact procedure, } \\
\text { Needed the fact } \\
\text { Procedure needed } \\
\text { Priority skale, }\end{array}$ & 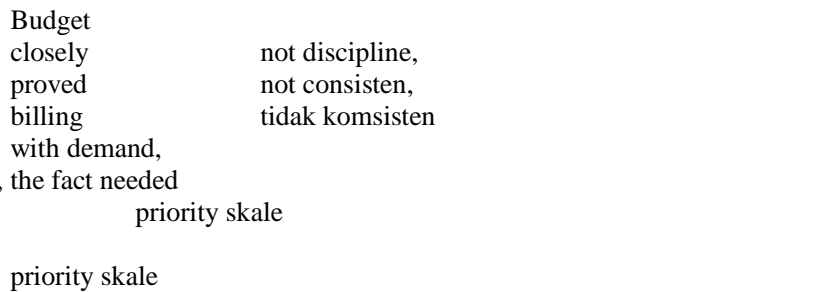 \\
\hline
\end{tabular}

Table 3.24. Invented Formulation Management Audit System Audit that have done at Site I SMP Terbuka Teratai, Site II SMP Terbuka Tulip, and Site III SMP Terbuka Mawar at the Malang Rgeion.

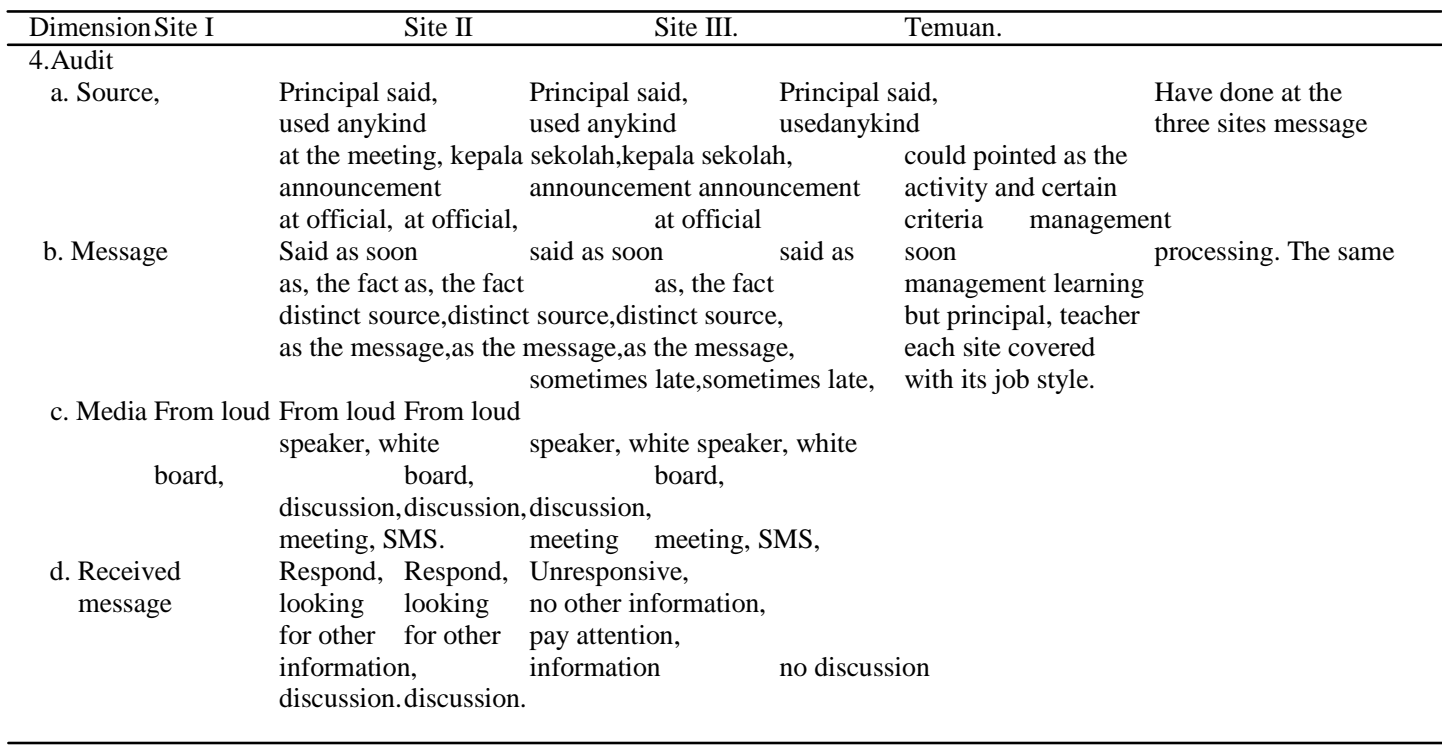

\section{Discussion}

At the chapter before have done data and research invented to each sites also analysis between site to ascertain the final research invented. In this chapter to explain the discussion about research invented from of the three sites research with empirical analysis and theory. This invented discussion included at the aim that result from whole focus research, were: the school management condition have done at 1. SMP Terbuka Teratai; 2. SMP Terbuka Tulip; and 3. SMP Terbuka Mawar at the Malang region. 


\section{Planned School about Management SMP Terbuka Teratai, Tulip and Mawar at the Malang Region}

Planned about management at SMP Terbuka Teratai Malang region, were; management attitude factor could seen from principal management dimension that supported, made the community known each management school, example principal effort to support the teacher to follow certification, given funding to the teacher were wanted to learn and changed all of the books where bought with bill, till asked the teacher have done management difficulty. Principal effort have done many with consent, like to return the money where have bought for the school.

Ability Principal dimension done school management ability have many occur changed basic, each management that have done always found teacher supporting and because a good management, useful and proven, mainly integrated with teacher competence problem at this school, indicasion could seen from prestige that from the school, community confidence against the school, and result of the student examination. Principal'concept, operasional and ability social relation integrated, could seen the prove.

Motivation dimension and desire, principal have done and responsible against the school, message with confidence sometimes everyone to curl, come early and back home lately, always worked at the school, active bought and read selt-motivation book, leadership and religious. Principal used its motorcycle, but always enjoy with their job. Everywhere to be principal could advanced that school, only with their discipline. (Tilaar, 1997:151) obtained "education have a function to teach each citizen, prepared power that have characteristic that desire for industrial, but not as that main responsible".

If all this phenomenal as proposition even surely that principal was a management that understood about task and responsible as the primcipal, ability a good management and have leadership material and experience as the leadership because have as a principal around 15 years, so that expert as the leadership. Finally that management attitude quality principal against management school have effort with the good till supported management at this school. The principal managed not formal because their very familiar.

Planned about management SMP Terbuka Tulip at the Malang Region, were; attitude factor management seen from dimension what must principal management was supported, given to the teacher to follow certification, funding for the teacher that wanted to learn and changed the money what books lesson have bought as the bill, till what difficulty of the teacher at the management school.

Principal ability dimension management school have many changed from the basic, each management always found supported from the teacher and result from the good management, useful and proven, integrated with teacher competence problem at this school, indicasion could seen from prestige that the school, community confidence against schdol and exanmination result student. Concept principal, operasional and social relationship have done good.

Principal motivation dimension, desire, and responsible against the school, always early come and than back home lately from the school, school to be a second home and religiously. Principal went to school with walking, never give up. Principal believed that motivation and discipline as the key for succeeding of the school.

If all this phenomena with accurate as proposition certainly that principal was a management that understood the task and responsible, have ability and a high motivation a good management. Finally the principal management attitude quality against management school have effort with good till supported management at this school and all as a formal

Planned about management at SMP Terbuka Mawar at the Malang Region, were; attitude factor have seen from management principal before supported, helped and seek way out alternative, at each management school, example principal efforted the teacher to follow certification, funding to the teacher that wanted to learn and changed the money books as the bill, till asked the difficulty of the teacher before done management. If also have done never not professional.

Principal ability dimension done management school the event have not changed, each management that have not supported from the teacher and its result unproved, the first integrated with competence problem teacher at this school.

Motivation dimension and desire, were principal have not managed and full responsible against the school, no message with confidence that have been given, sometimes principal early come and than fast back home, enjoy reading self-motivation book, leadership and religious and liked to say the difficulty.

If all this phenomena accurate as proposition could certainly that principal was not managerial that understood the task and responsible as principal, have not ability a good management, high motivation, responsible. Principal have experience to lead the school below 10 years, so have not seen as the leadership. Finally certainly that disposition quality and attitude principal against management school have been efforted but not yet good and supported at this school. Principal have done the management school with uncertain.

\section{Management Organization SMP Terbuka Teratai, Tulip and Mawar at the Malang Region}

Management organization SMP Terbuka Teratai at Malang Region with organization structure factor that principal have done for efficiency dimension was the clear job description with vice, vice have functional at 
their task with given confidence and full responsible, done the discipline and prosedure with clear job description have done vice and all the teacher, treasurer and administration as with their each ability. Principal always done at the school visi, misi as the model so that did what the real role, used the discipline, as the "softcopy" and "hardcopy" data file, noted and booked, bill proved and with excellent reported. Seek all the file with easily and kept with accurately, proved at this school. Principal ccordination dimension with given responsible, confidential, task totheir vice, teacher/tutor, treasurer and administration with purpose to make the coordination easily and done step by step. This thing impact at the useful good and exactly power source.

From the all phenomena would be seen at each dimension base structure factor organization, certainly that principal have done effort efficiency, clear design, coordination and useful good and exactly power source, so that relation organization could supported the management school. Since could be sure that organization structure have done.

Management organization SMP Terbuka Tulip at Malang Region with structure organization that principal have done for efficiency dimension was job description with vice and given confidential and full responsible, done discipline and procedure with clear. This job description have not done only vice, but teacher/tutor, treasure, adminitartion and student as its each job. Principal have done and always at the visi, misi, school as the model so as the real role, used the discipline, as the "softcopy" and "hardcopy" data file, noted and booked, bill proved and with excellent reported, discipline and regular. From coordination dimension principal with responsible, confidential, task vice, teacher/tutor, treasure and administration its purposed to make easily coordination and done it step by step. This thing impact at the useful power source, because all the power source to be excellent. Concept education constant average so difficulty to arrange it. Prysor-Jones (dalam Suryadi dan Tilaar, 1994:29)

All phenomena that organization Structure base factor struktur organisasi could seen from each dimension, certainly that principal have done many efficiency effort, clear design, coordination and useful good and exactly power source, so that organization relation could supported the management school. So that be surely organization structure have done with good and exactly.

Finally all the proposition known that the principal as a leader at this school have done anykind of the management that supported in each its action, seen from its communication attitude effort, power source and organization structure that have done with excellent. (UNESCO ASPnet School).

Management organizatian SMP Terbuka Mawar at Malang Region with organization structure factor that principal have done for efficiency dimension was the clea job description vice, made be funcsional the task to the vice with given confidential and full responsible, done dicipline with clear, and made the right responsible design at the procedural. As the principal have not done visi, misi school as model that purpose for eliminate the fault, done dicipline, noted and booked, bill proved and made a good report, and regular, but all practical have not done. Principal coordination dimension with given responsible, confidential, task to the vice, teacher/tutor, treasure and administration was that made the purpose easily coordination and done step by step. This thing impact to the useful power source, because all the power source have not as its function.

From all the phenomena organization structure factor base could seen to each dimension, certainly that principal have done anykind efficiency effort, used the clear design, done coordination and useful power source with a good and exactly, although have not yet ability, not exactly and that management school supported. So could surely that organization structure have not yet done.

\section{Development Power Source Management SMP Terbuka Teratai, Tulip and Mawar at the Malang Region}

Development power source management SMP Terbuka Teratai at Malang Region with power source factor could seen from the teacher/tutor invented not enough for any lesson, so that principal could not made policy to take several teacher/tutor for making a permanent teacher/tutor that have relevance skill as the school was needed, said to the teacher/tutor active to the academic activity, given informative technology at their room, made the a group sitting as their lesson so that could discussion, given permit and easily to the teacher/tutor done sminar activity, training etc.

For its infrastructure school that supported principal management till now still repaired and build sequence athletic; mosque and its all facility comfortable; a health classroom learning, comfortable and with informative technology, science laboratory (physics, chemical and biology), library, multi-media room and computer room. Principal have prepared all the maintenance infrastructure, so that the instrument constantly its condition with given laboratory, technician, pointed teacher/tutor a responsible and operation discipline procedure. Principal have done effort management school with full attention. Financed and source cost for this school only budget from the school committee, from center government and region, generating income and from sponsor at a special time. Funding of the school have other source only at the budget and enough for its cashflow. The budget of this school was used good enough with its needed and rational, priority scale financed, 
invoice bought, procedural and that have agreement fom principal and school conmittee. Sometimes principal not discipline useful the financed.

Anykind principal have done effort comunication management, anykind action that reach the goal, needed concrete, so each school management could done with excellent. The school problem power source have done with creative, objective and safety as the formal or nonformal. Surely that all aspect and dimension integrated with principal have done many power source with good at this school and exactly supported against school management. GSTaven@cbe.ab.ca.

Development power source have done management SMP Terbuka Tulip at the Malang Region with power source factor could seen from teacher/tutor as power source dimension invented not enough for any lesson, so that principal have taken policy with received several teacher/tutor, and function back that the teacher/tutor have pension for class have not its teacher/tutor, effort received the teacher/tutor have a relevance skill that as the school was needed and its experience, given permit and financed the teacher/tutor continue its study, given permit and the teacher/tutor followed seminar activity with easily, training etc.

Principal infrastructure facility school that supported a good management sequence athletic, mosque and the health classroom for learning, and informative technology, science laboratorium (physics, chemical and biology), library, multi-media classroom and computer classroom always repaired it. Institution by Principal have cared all infrastructure, so that the instrument always at the good condition, given facility technician, and its strong procedure used that discipline and responsible.

Source cost of this school onlu from the budget and financed from the government centre, region and institution, the cash-flow of this school enough. The useful budgeting very good because rational and as a needed, priority scale as budgeting with invoice bought, procedural and must have agreement from institution and principal.

Power source problem at this school enough good, objective, safe, good and formal or nonformal. So that certainly all the aspect and dimension, principal have done with good at this school and the management very supported.

Development management power source SMP Terbuka Mawar at Malang Region have seen with power source factor from the teacher/tutor invented still less its lesson, so that principal have taken policy with received several teacher/tutor, since each teacher/tutor not overlapping to teach. The teacher/tutor'honor effort to be a permanent teacher/tutor that have relevance skill as the school'need, sometimes given permit and easily to the teacher/tutor done its seminar activity, training and continue its study.

For facility physic infrastructure school that supported management principal till now still repaired and build sequence athletic, mosque and the health classroom for learning, and informative technology, science laboratorium (physics, chemical and biology) that dirty, library uninterested, multi-media room and computer room that simple. Principal not care the infrastructure not facility for laborer, technician, but received teacher/tutor that given responsible to care, although constant supported with useful procedure.

Source financed this school only from budget school committee, from the government centre, region and institution, the cash-flow of this school enough. The useful budgeting very good because rational and as a needed, priority scale as budgeting with invoice bought, procedural and must have agreement from institution and principal.

Sometimes principal not discipline in useful the financed. Principal several effort have done with management communication, action, needed concrete, projection, so each management school could done with good. Problem power source this school done not creative, objective and safe as formal or nonformal. So could be sure that all dimension and aspect that integrated with power source principal have done many, but not optimal and not to support management school.

\section{Management Audit System SMP Terbuka Teratai, Tulip and Mawar at the Malang Region}

Management audit system SMP Terbuka Teratai at the Malang Region with audit factor seen from source dimension, principal have done direct and said the message management effort to the teacher/tutor via anykind, announcement at the teacher/tutor room, official meeting with loudspeaker, and with a letter. From dimension message, usually message management said as soon as and principal'principle never to suspend, its source from fact that obvious, with accurate and its message not far from the hope visi, misi. From media dimension, message said via loudspeaker, announcement at blackboard in the teacher/tutor room, SMS although not yet all, discuss non-formal with the same teacher/tutor, but not used e-mail. From dimension receiver message, They are known and respond far about righteousness and message. (Schawandt \& Halpen, 1988:19)

Anykind effort that have done with anyway, as its any action so the message they said real could be known by the teacher/tutor with any respond to all and good. If principal said the message with common, individual and from loudspeaker, electronic and discuss. E-mail not yet used, because every teacher/tutor have not "address e-mail" although approach with formal or non-formal. So that be surely have many ways to say the 
management have done by the principal so could be received with conventional not with electronic and audit that have done real supported the management school. (Raka Joni, 1989).

Management audit system SMP Terbuka Tulip at the Malang Region with audit factor be seen from source dimension, principal have done said direct and the management message effort to the teacher/tutor with anyway, although announcement speaking and blackboard at teacher/tutor room and official meeting with loudspeaker. From message dimension, usually have said as soon as and principal'principle never to suspend, its source from fact that obvious, with accurate and its message not far from the hope visi, misi. From media dimension, message said via loudspeaker, announcement at blackboard in the teacher/tutor room, SMS although not yet all, discuss non-formal with the same teacher/tutor, but not used e-mail. From dimension receiver message, They are known and respond far about righteousness and message.

Anykind effort that have done with anyway, as its any action so the message they said real could be known by the teacher/tutor with any respond to all and good. If principal said the message with common, individual and from loudspeaker, electronic and discuss. E-mail not yet used, because every teacher/tutor have not "address e-mail" although approach with formal or non-formal. So that be surely have many ways to say the management have done by the principal so could be received with conventional not with electronic and audit that have done real supported the management school. (University of Nottingham, 2002)

Management audit system SMP Terbuka Mawar at the Malang Region with audit factor be seen from source dimension, principal have done said direct and the management message effort to the teacher/tutor with anyway, although announcement speaking and blackboard at teacher/tutor room and official meeting with loudspeaker. From message dimension, usually have said as soon as and principal'principle never to suspend, its source from fact that obvious, with accurate and its message not far from the hope visi, misi. From media dimension, message said via loudspeaker, announcement at blackboard in the teacher/tutor room, SMS although not yet all, discuss non-formal with the same teacher/tutor, but not used e-mail. From dimension receiver message, They are known and respond far about righteousness and message.

Anykind effort that have done with anyway, as its any action so the message they said real could be known by the teacher/tutor with any respond to all and good. If principal said the message with common, individual and from loudspeaker, electronic and discuss. E-mail not yet used, because every teacher/tutor have not "address e-mail" although approach with formal or non-formal. So that be surely have many ways to say the management have done by the principal so could be received with conventional not with electronic and audit that have done real supported the management school.

From the data that could be invented each to its school, that there are several things could be found as the conclusion spectacular when principal have done the condition of management school as the next.

a. Be seen from management school at the three SMP Terbuka impact against academic prestige, extra curricular and self-develop. That three of this SMP Terbuka were as the same favorite school, community trusted and prestige at the Malang Region so that many the parent of student have choosen because uniqueness and the most of the school.

b. Be seen from the three of SMP Terbuka above, that if principal have seen a quality in management school were (1) SMP terbuka Teratai Malang; (2) SMP Terbuka Tulip Malang; (3) SMP Terbuka Mawar Malang. Condition management school that quality would impact at the prestige school, and each school have most and less at SMP Terbuka Teratai different with SMP Terbuka Tulip, and if both of them compared with SMP Terbuka Mawar sure would different one to another.

c. Principal leadership as at SMP terbuka Teratai its condition management school more in itself leadership style as bureaucracy with its initiative, creative and high innovative, with supported and authority "concept skills, operational skills and human skills" that smart. Different with SMP Terbuka Tulip principal have done with leadership style as bureaucracy institution that sel-confidence and no comment outside of its responsible and authority that integrated with institution responsible. This things only to manage safety for its institution. SMP Terbuka Mawar principal'leadership style bureaucracy with not clear only done the management as its-self, and believed at the irrational that for its-self or its group.

d. Style at the SMP Terbuka Teratai principal have effort the condition management school more at the professional basic so principal more in creation for advancing the development school. Different with SMP Terbuka Tulip more effort at the role and rational that for normally, so that principal difficult for advancing the development school. Style at the SMP Terbuka Mawar effort toward more to "rational and irrational," so principal needed a long time for advancing its school because unclear and so lately in action. Principal could be so tired and maybe would be frustration and ill at last give up.

e. Seen the term of responsible from the three school: style at SMP Terbuka Teratai would appeared concept "our responsible," advanced or not the school as responsible together between principal, teacher/tutor, staff, student, government, and "stakeholders" that integrated. Different with at SMP Terbuka Tulip would appeared concept "my responsible," that advanced of this school very depend at the leadership principal, as 
the institution believer. Style at SMP Terbuka Mawar would appeared concept "your responsible," that advanced or not this school depend who is as the principal.

f. Seen from responsible that appeared term for the three school. The first, with characteristic at SMP Terbuka Teratai that principal have seen the responsible to whom done the management school was a "message" that must done with excellent and ready heart. Second, different with characteristic as at SMP Terbuka Tulip that responsible of the principal where have given as "favour" that must done with excellent and ready heart. Third, would be more different with characteristic as at SMP Terbuka Mawar that responsible of the principal at its-self as "message" that must done with high conscious.

\section{Conclusion}

From all the data and result analysis data at each site with analysis research multi-sites about "Management open Junior High School during the nine year compulsory education program" with study multisites SMP Terbuka Teratai, SMP Terbuka Tulip and SMP Terbuka Mawar at the Malang Region.

\section{School Planning about management at the three Sites SMP Terbuka at the Malang Region.}

Management school effort at SMP Terbuka principal and teacher/tutor that have done management planning have confirmed by school climated, made and easily relation one with another with ready heart to do it. Teacher/tutor have wanted, ability, and high commitment in management school planning, that could made management school with effective.

Principal have done with professional and proportional to school visi, and misi, with open and guard prestige school as the formal, able made functional, discipline and responsible

\section{Organization Management at the three Sites SMP Terbuka at the Malang Region.}

Structure organization management at the SMP Terbuka that principal have done with simple, effective and efficiency organization, creative, principal, vice, teacher/tutor with clear job description and responsible.

Managed as the standard reference, visi, misi school and budget, coordinated organization with made a good procedure and organization communication with a good responsible functional.

Organization have done its-self because with consciously from each teacher/tutor, principal as a leader that have a power because there are supported from the teacher/tutor and staff at the school.

\section{Development Power Source Management at the three Sites SMP Terbuka at the Malang Region.}

Development power source effort management that have done at the SMP Terbuka principal have done made training, lokarya, seminar, reacher, discussion in and out of the school and made the same lesson group at the teacher/tutor rooms.

If humanity source with quantity and quality have balance, then would occurred acceleration and success in management school.

Facility with complete instrument were prepared at school would given positive impact against acceleration known the technology that build self-confidence to the teacher/tutor at the school, but with quality would impact against to reform creative level and innovation each person at the management school.

Implementation the management school supported with a good finance management, so that the education would be advanced and good character. And power source that prepared at the school have could used as the optimal by the principal, teacher, and student, that would good impacted against the quality support and done at the management school.

\section{Management Audit System at the three Sites SMP Terbuka at Malang region.}

Effort audit management audit system at the SMP Terbuka that have done by the principal school at the good environmental school and attentively social, so that implementation the management school would more effective and good. Management audit school that effective would happened if supported by source information direct that could responsibility, good from skill in said, reference that supported information as direct, although that accurated in the right level and could believed at the credibility. The warm messaged, from the clear fact, careful with not far from the vision and mission that be hoped. Media that used as much, made easily to said the information and that true representative and for the receiver believed have represent ordered that would be said.

Implementation management school at the three SMP Terbuka impacted against taken academic prestige, extra curriculer and self-develop. That the three SMP Terbuka this was together as the favorite school, be believed by community and prestige at Malang region so many the parents of student needed with any more and unique each that school. The three SMP Terbuka above, that if be seen quality each principal at the management school there was (1) SMP terbuka Teratai Malang; (2) SMP Terbuka Tulip Malang; (3) SMP Terbuka Mawar Malang. Condition management school that quality would impacted at the good quality school, and each school have more and less. SMP Terbuka Teratai different with SMP Terbuka Tulip, and if the two be 
compared with SMP Terbuka Mawar certainly far would different one the others. Principal leader'style as at the SMP terbuka Teratai more exactly if condition management school that implementation by principal with leader style as government bureaucracy with the high initiative, creative and innovative, with have supported a good concept skills, operational skills and human skills and smart. Differently with as at SMP Terbuka Tulip style if principal implementation with leader style as bureaucracy institution that self-condifence and no comment out of responsible and authorize at main things that integrated wuth institution responsible. This thing metaphor as film-star that only done and safe-guard for own institution. Therefore for at SMP Terbuka Mawar principal leader style that as a government bureaucracy that did not clear its mind only orientation at its own, implementation management as its own, and believed at the thins irrational that for himself or their group. Style as at SMP Terbuka Teratai principal efforted implementation school mnanagement condition more orientation at the base "professional and scientific," so that principal more Could advanced development its school creation. Different with style as at SMP Terbuka Tulip more effort stress to basic "rule and rational" that done as normally, so that principal not usually and limited in development the school advanced. And at SMP Terbuka Mawar style with efforted that toward stress more at the basic "rational and irrational" So the principal felt lately and needed a long time for advance the school. Responsible that appeared for the three school: for at SMP Terbuka Teratai style would appeared concept "our responsible," that advanced or not the school as responsible together between principal, teacher/tutor, staff, student, government and stakeholders that integrated. Different with at SMP Terbuka Tulip style would appered concept "my responsible," that advance of the school depend on of the leader that principal as institution believer. And at SMP Terbuka Mawar style would appeared concept "your responsible," that advanced or not the school was depended to who that as a principal. Seen from the responsible that must be front appeared term for the three school. first, with characteristic at SMP Terbuka Teratai that a principal seen the responsible that have given to someone for implementation management school was as "message" that must be done with care, good and full-heart. Second, different with characteristic as at SMP Terbuka Tulip that principal seen responsible that have given to himself was as "grace" that must be done with good as soul-call. Third, would different again with characteristic as at SMP Terhbuka Mawar that principal responsible to himself as "message" that must be done during this time till have awared himself that high for repenting.

\section{B. Research Implication}

Implication and this research invented included two things, that theorist implication and practical implication. Theorist Implication relation with it contribution yes for developing education management theories and pratical implication that integrated with contribution research invented against implementation management school.

\section{Theorist Implication}

Theorist implication this research integrated with planning management school as the theory, this research have been awared that relation between planing management school could not separated both of its as same as the urgent and each supported always dynamics development. At once this research'result have limited although from its methodology or study as deeply about relation between factor that would be research, although as common could given theorist implication agreed with management and school organization, also coherency with quality and school efective in reaching the gol and target management school.

(Muhadjir, 2004:43), education management as efforted for social problem solution to be social problem for community on justiced and prosperity. (Cooper, 2004:3) said that policy as process politics where have be needed, gol and intensity that have done in objective view, law and program.

Study for the next that integrated with application and development management power source must be started with process reresearch at the management, also the target and aim. Managed Management education done school management, target and aim into strategy and operational management, and researched how have operational management? That have communication to managed management, power source have been prepared and useful, system and build the job description with implementation directly and development to competence. The next, research how to manage the management audit system education, and research more about the result quality and quantity, so that quality output as competence technician, managerial, attitude, skill, relevance quality output with needed, efficiency in education management.

(Tilaar, 1997:151) said "education have managed and function for teaching each citizen, and preparing power that have characteristic be needed for the industry-field, not as a main responsible."

All of that in contexts education managemen, that formulated, determination, management with outcomes. Theorist implication more the next, that where was laid its results and failure school management implementation? What was formulated and determination or at itself management process?

(Buchori, 2001:7) said that each nation where true needed to prepare himself for the future, must be born to do the changes at the education system, although at the formal education or non-formal education. 


\section{Practical Implication}

As macro for formulating and determination school management needed to socialization more professional again, so that each managed could received message management with a good and not uncertain about it. In the future could be hoped to manage and give input and respond accommodate to be material balanced in formulating management that the future.

And as mikro as the next; First, planing school at the staff for managing each school management at a good needed. So that planning to care or to increase needed our supported development system and sat the right and good teacher/tutor. Principal neede to create climate school that conducive so that could done the management that teacher/tutor included at the formulate managed management and be hoped their as proactive to follow and give input at the school management operasional that its mean.

Second, managed organization that there are have done with a good unless at SMP Terbuka Mawar not yet at its function as be hoped, although constantly needed to arrange a good job system and procedure so that coordination between principal with the teacher/tutor good as internal or external could be increased. Principal needed to arrange standard operational procedure each school, so that could be happened fragmentation elimination.

Third, development power source managed management that have be prepared to need a better planning, useful and development, so that supported the effective and efficiency managed management. Each principal must efforted to make teacher/tutor surely done management reformation for the school future living. Conceling activities supervision learning, training and others felt very useful by all stakeholders. So that relation between principal with teacher/tutor as priority and continuously needed to increase relation functional used to increase again extension service as sustained, so could be reached to increase a good job. Useful result research needed supported by received teacher/tutor, so that between principal with teacher/tutor have standard operational procedure that clear in selection teacher/tutor that needed as each skill. Selection system managed to select a new teacher/tutor have a target for increasing quality teacher/tutor. Concept development test material and system determination the pass examination that principal have done, needed to be know to each teacher/tutor. Test managed or selection needed a good cooperation between principal, unit test managed that have been pointed and prepared the place for testing. So that test managed could happened with good and reached target that have needed.

Fourth, management audit system that relation with increased competence teacher/tutor at each school have audited to all management manged, but the management have not yet uniform perception by all management managed. Principal must be increased message quality that said to teacher/tutor from understanding "what, why, who, when, where, and how" about increased management competence teacher/tutor that means so to be more clear. Beside that each principal needed formulation strategies steps in increased effective communication management to all teacher/tutor. Henceforth be hoped teacher/tutor as proactive given feedback for perfecting message substance that be said their each principal. Management managed education needed to use this research result as the priced modal for developing school sustain. Would be better, if management managed education needed supported across school in doing and used modal that have been by stakeholders or with model transfer rotation as that have done at this last-day education service office at Malang region. This thing could to be also as efforted managed and with academic development teacger/tutor to be more interested. Henceforth management managed education with model regular or entrus needed to start and managed soon. Principal and teacher/tutor must be effort to increase quality process leraning that relation with management school, integrated with focus material that be said to student task, the power practical that competence and prepared material teaching that be needed as condition at the field. Be hoped Education Service could be sat a new teacher/tutor as with it competence that their having, so that could managed task and function as optimal

\section{Suggestion}

The basic of all analysis, research suggestion could used with hoped and benefit to:

1. For government Malang Region, in this thing education service at Malang region specially government instance that integrated with basic education as of nine year compulsory education of open junior high school at Malang region, this research invented could considered as one of foundation or input at done monitoring and evaluation or assessment against management managed of nine year compulsory education of open junior high school each a far region. with thus could done to repaire actions and development toward that more good so reached the target as with membership school hoping, community and government.

2. For Education Service Province and Excuting ministry in science development, this research result could hoped to be input for ascertain the policy more advanced and development education basic for nine year.

3. For Principal, specially SMP Terbuka at Malang region, this research result as material input for monitoring and evaluation against the management of nine year compulsory education of open junior high school so 
that could be increased in reaching that maximal target policy program of nine year compulsory education of open junior high school.

4. For others research, be hoped could to be inspiration for researh and scientific task and could be considered as material reference for that wanted to do sustain research with used approached design as the same research, and/or approached the different research.

\section{References}

[1] Abdullah. 2004. Professional Development for SD Teacher Through School Cluster, Teacher in Indonesia Their Education, Training and Struggle and Secondary Education. Jakarta: Ministry of Nasional Education of The Republic Indonesia.

[2] Achmady, Z.A. 1994. Kebijakan Publik dan Pembangunan. Malang: IKIP MALANG.

[3] Alberta, C. 2006. Terry Fox Junior High School has been a national accredited UNESCO ASPnet School. (online) (ASPnet) diakses tanggal 15 Juli 2010.

[4] Anderson, J. E. 1979. Public Policy Making. New York: Holt, Rinehart and Winston.

[5] Arie, P. 1988. "Planning Learning." Harvard Business Review. March - April, pp 70 - 74

[6] Bogdan, R.C. dan Biklen, S.K. 1998. Qualitative Research for Education: an Introduction to Theory and Methods. Needham Heigths, MA: Allyn \& Bacon A Viacom Company.

[7] Buchori, M. 2001. Transformasi Pendidikan. Jakarta: Pustaka Sinar Harapan.

[8] Burhanuddin. 2002. Manajemen Pendidikan: Wacana, Proses dan Aplikasinya di Sekolah. Malang: Universitas Negeri Malang.

[9] Cooper, B.S. 2004. Better Policy Better School, Theories and Application. Boston: Pearson Education.

[10] Creswell, J.W. 2005. Education Research Planning, Conducting, and Evaluating: Quantitative and Qualitatif Research. New Jersey: Upper Saddle River.

[11] David, T. GST. Aven. 2010. Old Junior/Senoir High School. (online) (http://www.isflst.ca. dan davidthian@shaw.ca. dan GSTaven@cbe.ab.ca.) diakses 17 Juli 2010.

[12] Departemen Pendidikan dan Kebudayaan. 1990. Peraturan Pemerintah RI Nomor: 28 Tahun 1990 Tentang Pendidikan Dasar. Jakarta: Departemen Pendidikan dan Kebudayaan.

[13] Departemen Pendidikan dan Kebudayaan. 1992. Pedoman Pelaksanaan Sistem SMP Terbuka. Jakarta: Proyek Peningkatan Kebijaksanaan Operasional Pembangunan dan Pengorganisasian Departemen Pendidikan dan Kebudayaan.

[14] Departemen Pendidikan dan Kebudayaan. 1993. Keputusan Menteri Pendidikan dan Kebudayaan No. 54/U/1993 Tentang Sekolah Menengah Pertama (SMP). Jakarta: Departemen Pendidikan dan Kebudayaan.

[15] Departemen Pendidikan Nasional. 2003. Undang-undang Nomor 20 Tahun 2003 Tentang Sistem Pendidikan Nasional. Jakarta: Depdiknas.

[16] Departemen Pendidikan Nasional. 2005. Bahan Sosialisasi SMP Terbuka Dalam Rangka Penuntasan Wajib Wajib Belajar Pendidikan Dasar 9 Tahun. Jakarta: Depdiknas.

[17] Departemen Pendidikan Nasional. 2005. Peraturan Pemerintah Republik Indonesia Nomor 19 Tahun 2005 Tentang Standar Nasional Pendidikan. Jakarta: Depdiknas.

[18] Departemen Pendidikan Nasional. 2005. Petunjuk Operasional SMP Terbuka. Jakarta: Direktorat Pembinaan Sekolah Menengah Pertama, Direktorat Jenderal Manajemen Pendidikan Dasar dan Menengah Depdiknas.

[19] Departemen Pendidikan Nasional. 2005. Petunjuk Pengelolaan TKB Mandiri. Jakarta: Direktorat Pembinaan Sekolah Menengah Pertama, Direktorat Jenderal Manajemen Pendidikan Dasar dan Menengah Depdiknas.

[20] Departemen Pendidikan Nasional. 2006. Peraturan Menteri Pendidikan Nasional RI Nomor: 35 Tahun 2006 Tentang Gerakan Nasional Percepatan Wajib Belajar 9 Tahun. Jakarta: Depdiknas.

[21] Departemen Pendidikan Nasional. 2006. Rencana Strategis Departemen Pendidikan Nasional 2005-2009 Menuju Pembangunan Nasional Jangka Panjang 2025. Jakarta: Depdiknas.

[22] Departemen Pendidikan Nasional. 2007. Pengembangan Bakat Non-Akademik: Pengembangan Kemampuan Manajerial. Jakarta: Depdiknas.

[23] Departemen Pendidikan Nasional. 2007. Peraturan Menteri Pendidikan Nasional Republik Indonesia No. 19 Tahun 2007 Tentang Standar Pengelolaan Pendidikan Oleh Satuan Pendidikan Dasar dan Menengah. Dalam Warta Hukum dan Perundang-undangan, Vol. 8, No. 3, Desember 2007:p. 19-35. Jakarta: Biro Hukum dan Organisasi Depdiknas.

[24] Devlin, L. 1989. “A Closer Look.” Canadian Journal of University Continuing Education. Vol.15. No. 1.pp 29 - 38.

[25] Djojonegoro, W. 1996. 50 Tahun Perkembangan Pendidikan Indonesia. Jakarta: Depdikbud.

[26] Duke, D.L. \& Canady, R.L. 1991. School Policy. New York: McGraw-Hill.

[27] Dunn, W. 2000. Pengantar Analisis Kebijakan Publik. Penyunting Muhajir Darwin. Yogyakarta: Gadjah Mada University Press.

[28] Fahrurroji, M. 2008. Mengukur Keberhasilan Wajar Dikdas 9 Tahun dan Kesiapan Wajar Dikmen 12 Tahun yang Bermutu di Kota Samarinda. www.mfahrurroji.blogspot.com, diakses tanggal 12 Agustus 2008.

[29] Faisal, S. 2005. Format-format Penelitian Sosial. Jakarta: RajaGrafindo Persada.

[30] Fattah, N. 2008. Landasan Manajemen Pendidikan. Bandung: Remaja Rosdakarya.

[31] Georg, S. 1987. "Strategic Control: A New Perspective.: Academy of Management Review. January, pp 91 - 103.

[32] Hodgetts, R. M. 1990. Management Theory, Process, and Practice. San Diego: Harcourt Brace Jovanovich, Publishers.

[33] Ikatan Sarjana Pendidikan Indonesia (ISPI). 1995. Pendidikan dan Prospeknya Terhadap Pembangunan Bangsa Dalam PJP II. Jakarta. Ikatan Sarjana Pendidikan Indonesia (ISPI).

[34] Instruksi Presiden RI. No. 1 Tahun 1994 tentang Wajib Belajar Pendidikan Dasar 9 Tahun. Jakarta: Sekretariat Negara RI.

[35] Indonesia. 1997. Ministry of Education and Culture Education Development Indonesia. Jakarta.

[36] Irawan, B. S. 2008. Analisis Kebijakan Pertahanan. www.buletinlitbangdephan.gi.id, diakses tanggal 13 Agustus 2008.

[37] Jalal, Fasli dan Dedi Supriyadi (Ed.). 2001. Reformasi Pendidikan Dalam Konteks Otonomi Daerah. Yogyakarta: Adicita Karya Nusa.

[38] Lincoln, YS \& Guba EGL. 1985. Naturalistic Inquiry. Beverly Hill. CA: SAGE Publications, Inc.

[39] Maisyaroh, dkk. (ed.). 2004. Perspektif Manajemen Pendidikan Berbasis Sekolah. Malang: Universitas Negeri Malang

[40] Majelis Permusyawaratan Rakyat Republik Indonesia. 2006. Panduan Pemasyarakatan Undang-undang Dasar Negara Republik Indonesia Tahun 1945. Jakarta: Sekretariat Jenderal MPR RI.

[41] Meyer, R. R. dan Greenwood, E. 1984. Rancangan Penelitian Kebijakan Sosial. Jakarta: Rajawali.

[42] Miarso, Yusufhadi. 1985. Suatu Model Teknologi Pendidikan Untuk Pemerataan Kesempatan Pendidikan di Indonesia. Yogyakarta: Adicita Karya Nusantara

[43] Miarso, Yusufhadi. 2007. Menyemai Benih Teknologi Pendidikan. Jakarta, Kencana. 
[44] Miles, M.B. dan Huberman, A.M. 1992. Qualitative Data Analysis: a Sourcebook of New Methods. London: Sage Publications.

[45] Moleong, L.J. 2005. Metodologi Penelitian Kualitatif. Bandung: Rosdakarya.

[46] Muhajir, N. 2004. Metodologi Penelitian Kebijakan dan Evaluasi Research (Integrasi Penelitian, Kebijakan dan Perencanaan). Yogyakarta: Rake Sarasin.

[47] Mulyana, D. 2008. Metodologi Penelitian Kualitatif. Bandung: Remaja Rosdakarya.

[48] Nazir, A. S. 2002. Knowledge Management. FAQ. Buletin: Department of Information Systems, FSKSM, UTM.

[49] Patton, M. Q. 1990. Qualitative Evaluation and Research Methods. Second Edition, Newbury Park: SAGE Publications Inc.

[50] Patton, M. Q. 2006. Metode Evaluasi Kualitatif (How To Use Qualitative Methods in Evaluation). Yogyakarta: Pustaka Pelajar.

[51] Patricia, N. F. 1987. “Communation Skills Training for Selected Supervisors.” Training and Develop Journal, July, pp 67 - 70.

[52] Prasetyo. 2007. Ceramah ISO 9001:2000 (online) (http://prasetyo brawijaya.ac.id/agu04.htm\#iso)

[53] Pemerintah Kota Malang. 2009. Profil Pendidikan Kota Malang Tahun 2009. Malang: Pemerintah Kota Malang.

[54] Purwanto, N. 2006. Administrasi dan Supervisi Pendidikan. Bandung: Remaja Rosdakarya.

[55] Peter M. 1956. Bueaucracy in Modern Society. New York: Random House, pp 28 - 33.

[56] Rahardjo, D. 1997. Relevansi Iptek Profetik Dalam Pembangunan Masyarakat Madani. Academika, Vol. 01, Th. XV, hal. 17-24.

[57] Raka J, 1989. Pendidikan Profesional Guru, Malang: Universitas Negeri Malang.

[58] Randall, S. H. 2010. The Importance of The High School Junior Year. (online) (http://www.quintcareer.com). Diakses tanggal 17 Juli 2010.

[59] Rochaety, E, dkk. 2005. Sistem Informasi Manajemen Pendidikan. Jakarta: Bumi Aksara.

[60] Ross, T. 1998. A Principal's Intterruption; Time Loss or Time Gained? International Journal Education Management. 12 June, pp $244-249$.

[61] Samanan, A. 2008. Analisis Kebijakan SD-SMP Satu Atap Dalam Percepatan Program Wajib Belajar 9 Tahun di Kabupaten Jember. Tesis tidak diterbitkan. Malang: Program Studi Magister Kebijakan dan Pengembangan Pendidikan Program Pascasarjana Universitas Muhammadiyah Malang.

[62] Sarwono, J. 2003. Strategi Melakukan Penelitian di Internet. World Wide Web: http://js.unikom.ac.id

[63] Schawandt, T.A. dan Halpern, E.S. 1988. Linking Auditing and Metaevaluation: Enhancing Qualityin Applied Research. Newbury Park, Beverly Hills, London, New Delhi: Sage Publication.

[64] School Accountability Report Card. Reported for School Year. 2009 - 2010. Published during 2010 - 2011. (online) (http://www.cde.ca.gov/ta/ac/sa/.) diakses 19 Juli 2010.

[65] Sergiovanni, T. J. 1987. "Symbolism in Leadership: What Great Leaders Know that ordinary Ones do not," Paper Present to the Institute of Education Administration. Geelong, Victoria.

[66] Sidi, I. D. 2001. Menuju Masyarakat Pembelajar (Menggagas Paradigma Baru Pendidikan). Jakarta: Paramadina.

[67] Sonhadji, K. H. A. 1994. Teknis Pengumpulan dan Analisis Data dalam Penelitian Kualitatif. Malang: Kalimasada.

[68] Stuart, W. 2008. A Review of the Implementation of nine years Universal Basic Education, USAID, Indonesia

[69] Sudijarto. 1997. Memantapkan Kinerja Sistem Pendidikan Nasional dalam Menyiapkan Manusia Indonesia Memasuki Abad ke-21. Bandung: Rosdakarya.

[70] Suharsaputra, U. Pemerataan Pendidikan. www.lappkipnikng.com, diakses tanggal 12 Agutus 2008.

[71] Sukmadinata, N. S. 2007. Pendidikan Dasar. Jakarta: Universitas Pendidikan Indonesia.

[72] Sukriswandari, N. 2005. Analisa Singkat Perkembangan Pelaksanaan Program Penuntasan Wajar 9 Tahun yang Bermutu. Pelangi Pendidikan II: hal. 57.

[73] Supandi, A. S. 1988. Kebijaksanaan dan Keputusan Pendidikan. Jakarta: P2LTPK

[74] Supriadi, D. 2004. Membangun Bangsa Melalui Pendidikan. Bandung: Remaja Rosdakarya.

[75] Suryadi, A. dan Tilaar, H.A.R. 1994. Analisis Kebijakan pendidikan: Suatu Pengantar. Bandung: Rosda Karya.

[76] Sutopo, H.B. 2003. Pengumpulan dan Pengolahan Data Dalam Penelitian Kualitatif. Dalam buku Metodologi Penelitian Kualitatif: Tinjauan Teoritis dan Praktis. Editor Masykuri Badri, dkk. Malang: Lembaga Penelitian Universitas Islam Malang.

[77] Syafaruddin. 2002. Manajemen Mutu Terpadu dalam Pendidikan: Konsep. Strategi dan Aplikasi. Jakarta: Grasindo.

[78] Tilaar, H.A.R. 1997. Pengembangan Sumber Daya Manusia Dalam Era Globalisasi, Visi, Misi dan Program Aksi Pendidikan dan Pelatihan Menuju 2020. Jakarta: Grasindo.

[79] Tilaar, H.A.R. 2002. Membenahi Pendidikan Nasional. Jakarta: Rineka Cipta.

[80] University of Nottingham. University Quality Handbook 2002/2005. Download. 24 Agustus 2010. Pk. 10.00.

[81] Yin,. R. K. 1984. Case Study: Design and Method. Thousand Oaks, C.A: Sage Publications, Inc.

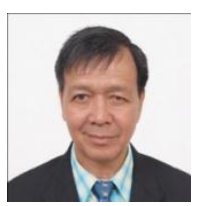

\section{Dr. Ir. Soetyono Iskandar, M.T.,M.Pd NIP 195403151981031004}

